\title{
The distribution and severity of beech bark disease in the Catskill Mountains, N.Y.
}

\author{
J acob M. Griffin, Gary M. Lovett, Mary A. Arthur, and Kathleen C. Weathers
}

\begin{abstract}
The distribution and severity of beech bark disease (BBD) in the Catskill Mountains of southeastern New York state, U.S.A., were measured between 1997 and 2000. Forest composition was measured using wedge prism surveys and fixed-area plot counts of canopy species. BBD severity on individual trees was ranked from 1 (no disease) to 5 (dead) based on bark health and canopy loss. These data were analyzed at multiple spatial scales to determine possible controls of disease distribution and severity. BBD was present on almost all Fagus grandifolia Ehrh. (American beech) individuals encountered $>10 \mathrm{~cm}$ diameter at breast height, but was most severe in larger diameter classes. Mortality due to BBD also increased with diameter class. A strong positive relationship was found between BBD severity and relative beech basal area at the tract (hundreds of hectares) and 100-m elevation band spatial scales, but not found at smaller scales. Successful long-range dispersal of the disease may therefore be dependent upon host density, while local conditions may control BBD severity within individual stands. The current status of BBD in the Catskills suggests these forests are entering the aftermath phase of the disease's progression and that BBD has become an endemic component of these forests.
\end{abstract}

Résumé : La distribution et la sévérité de la maladie corticale du hêtre dans les monts Catskills du sud-est de l'État de New York aux États-Unis ont été mesurées entre 1997 et 2000. La composition de la forêt a été évaluée par un inventaire au prisme et le décompte des espèces dominantes dans des placettes à aire fixe. La sévérité de la maladie a été classée de 1 (sain) à 5 (mort) sur chaque arbre en se basant sur l'état de santé de l'écorce et la perte de cime. Ces données ont été analysées à plusieurs échelles spatiales pour déterminer les facteurs potentiels qui régissent la distribution et la sévérité de la maladie. La maladie était présente sur presque tous les hêtres à grandes feuilles (Fagus grandifolia Ehrh.) présents de plus de $10 \mathrm{~cm}$ au diamétre à hauteur de poitrine mais elle était plus sévère dans les plus fortes classes de diamètre. La mortalité due à la maladie augmentait aussi avec la classe de diamètre. Une relation positive étroite a été observée entre la sévérité de la maladie et la surface terrière relative des hêtres à l'échelle spatiale de la parcelle (centaines d'hectares) et de la bande de $100 \mathrm{~m}$ d'altitude mais pas à de plus petites échelles. La dispersion de la maladie sur de longues distances est par conséquent possiblement dépendante de la densité de l'hôte tandis que les conditions locales contrôlent vraisemblablement la sévérité de la maladie dans chaque peuplement. La situation présente de la maladie dans les Catskills indiquent que ces forêts entrent dans la phase finale de la progression de la maladie et que celle-ci est devenue une composante endémique de ces forêts.

[Traduit par la Rédaction]

\section{Introduction}

Since its introduction to North America from Europe ca. 1890 (Ehrlich 1934), beech bark disease (BBD) has rapidly spread across the northeastern United States and southeastern Canada, with initial mortality rates of mature beech reaching 80-90\% (Houston 1984). High susceptibility of American beech (Fagus grandifolia Ehrh.) to the disease complex ensures both continued spread of the disease into uninfected forests and its establishment as an endemic component of previously infected areas. The legacy of massive initial damage immediately following the introduction of $\mathrm{BBD}$ and the continuous effects of endemic disease in long-

Received 20 August 2002. Accepted 31 March 2003.

Published on the NRC Research Press Web site at http://cjfr.nrc.ca on 18 August 2003.

J.M. Griffin, ${ }^{1}$ G.M. Lovett, and K.C. Weathers. Institute of Ecosystem Studies, Box AB, Millbrook. NY 12545, U.S.A.

M.A. Arthur. Department of Forestry, T.P. Cooper Building, University of Kentucky, Lexington, KY 40546-0073, U.S.A.

${ }^{1}$ Corresponding author (e-mail: griffinj@ecostudies.org). infected forests are both important factors influencing the current health and local distribution of beech, as well as overall forest composition.

Beech bark disease is caused by the interaction between the wingless scale insect Cryptococcus fagisuga Lind. (Hemiptera: Eriococcidae) and one of two species of Ascomycete fungus, Nectria coccinea (Pers.: Fr.) Fr. var. faginata Lohman, A.M. Watson, \& Ayers and Nectria galligena Bres. in Strass. The parthenogenetic reproduction of Cryptococcus allows for rapid population increase (Hepting 1971), and the combined feeding of many Cryptococcus individuals predisposes the bark to Nectria spp. infection via a mechanism that is not well understood. The resulting fungal colonies cause the formation of cankers on the bark surface, and the accumulation of cankering on an individual tree leads to the wilting of leaves, loss of twigs and branches, crown breakage, and eventual death (Boyce 1961). Since initial Cryptococcus damage is a prelude to the severe Nectria infection associated with BBD, the spread of BBD is largely governed by the wind- and animal-borne dispersal of Cryptococcus. After 3-5 years of scale insect population buildup on an individual beech, enough damage occurs for Nectria to be- 
come established (Tainter and Baker 1996). Despite limited natural controls that operate locally, such as predation of Cryptococcus by the twice-stabbed ladybird beetle, Chilocorus stigma Say, and competitive exclusion of Nectria by the fungus Ascodichaena rugosa Butin (Blanchard and Tatter 1981), no landscape-scale natural controls of BBD are known. At present, it seems that BBD is likely to become established everywhere within the range of beech that remains above $-37^{\circ} \mathrm{C}$, the fatal temperature for Cryptococcus (Tainter and Baker 1996).

In Europe, BBD has been known since the 1840s and is currently found wherever European beech (Fagus sylvatica L.) is growing (Tainter and Baker 1996). Since its inadvertent introduction via ornamental beech trees into North America at Halifax, Nova Scotia, in 1890, BBD has spread rapidly, first appearing in the United States in Maine in 1929. The zone of infestation has been spreading at the rate of $10-15 \mathrm{~km} /$ year, and by 1950 , most of Maine was affected. By 1960, New Hampshire, Vermont, Massachusetts, Rhode Island, Connecticut, and eastern New York were within the range of Cryptococcus spread. By 1975, most of New York, northern New Jersey, and northeastern Pennsylvania were infested with the scale insect, as well as all of Nova Scotia, New Brunswick, and eastern Quebec. Today, the disease is present in the northeastern United States as far west as Michigan (McCullough et al. 2000), Ohio, parts of West Virginia and Virginia, and as far south as isolated pockets in North Carolina and Tennessee (Houston 1994).

Shigo (1972) described this unchecked spread of BBD in three stages. The "advancing front" consists of rising Cryptococcus populations and low levels of Nectria. The "killing front" follows, characterized by large populations of Cryptococcus, severe outbreaks of Nectria infection, and high beech mortality. Shigo's final stage, the "aftermath", consists of evidence of prior mortality, few older trees, and beech thickets made of small trees of sprout origin. Houston (1984, 1994) further suggests that lower levels of scale insect populations and widespread defect of trees characterize $\mathrm{BBD}$ in these aftermath forests rather than the high Cryptococcus populations and high mortality rates experienced by mature beech forests in the killing phase.

Many studies have documented the effects of BBD on forests. For example, the phenomenon of prolific root sprouting by dead and dying stems can greatly alter the distribution of beech diameter classes (Fahey 1998). Root sprouting may also aid in the establishment of BBD as an endemic by retaining and proliferating susceptible genotypes within the population (Houston 1975). In maturing Adirondack northern hardwood forests, McGee (2000) found that for six decay classes of beech coarse woody debris, 55-100\% of the debris was attributable to BBD. Areas in which BBD is severe have experienced reductions in beech because of mortality, growth loss, and replacement by other species such as hemlock (Tsuga canadensis (L.) Carrière) (Twery and Patterson 1984). High mortality rates of large beech trees also create numerous gaps in the canopy. DiGregorio et al. (1999) found that these gaps increased the radial growth of sugar maple (Acer saccharum Marsh.) on gap edges as well as subcanopy trees within the gaps. At higher gap densities, the same study found that an increase in radial growth also occurred in subcanopy trees in nongap areas. The frequency of gap formation is an important mechanism in determining which species achieve canopy status. A study of Adirondack forests (Canham 1988) suggested that canopy beech trees would increase in abundance during periods of no canopy disturbance, while periods with high rates of canopy disturbance would increase the abundance of canopy sugar maple trees. High gap frequencies created by BBD mortality could therefore have two effects on canopy composition: the initial physical removal of canopy beech trees and the subsequent promotion of other species as replacements. In the Catskills, we observed that the most common species replacing beech was sugar maple. Such changes in forest composition initiated by BBD are a concern because the species that replace beech may differ significantly from beech in their effects on the nitrogen cycle of the forest (Lovett et al. 2002, 2003). Although current BBD severity alone does not explain $\mathrm{N}$ loss as stream $\mathrm{NO}_{3}{ }^{-}$from these watersheds (Lovett et al. 1999), the potential changes in vegetation composition caused by BBD mortality may induce shifts in nitrogen retention, loss, and distribution in these forests.

The Catskills were one of the first areas of New York state to be affected by BBD. As the largest and most well known wave of disease was first spreading into Maine from Nova Scotia and New Brunswick around 1935, one of several smaller waves of disease spread had begun when a Cryptococcus population was established near the port of New York City (Houston 1994). Cryptococcus populations were present in Westchester and Nassau Counties by the early1930s, and had moved north to become established in Catskill forests and surrounding areas by the 1940s (Houston 1984). The purpose of this paper is to describe the current distribution and severity of BBD in the Catskill Mountains, determine any spatial patterns in occurrence or intensity, and discuss past and future effects of BBD on these forests.

\section{Materials and methods}

\section{Site description}

The Catskill area is an uplifted peneplain of roughly $2500 \mathrm{~km}^{2}$ with flat-topped mountains and deeply incised valleys located in southeastern New York state, U.S.A. (Fig. 1). The vegetation of the zone roughly between 500 and $1100 \mathrm{~m}$ elevation is typical of northern hardwood forests throughout the northeastern United States. McIntosh (1972) reported sugar maple to be the most common tree in the Catskills, being present in $81 \%$ of the stands sampled and the leading dominant in $27 \%$ of them. Beech was second, being present in $70 \%$ of the stands and the leading dominant in $16 \%$, and yellow birch (Betula alleghaniensis Britt.) was third (present in $61 \%$, dominant in $9 \%$ ), though most of the latter were found at over $883 \mathrm{~m}$ elevation. Other common trees were hemlock, white ash (Fraxinus americana L.), and red oak (Quercus rubra L.), with balsam fir (Abies balsamea (L.) Mill.) and red spruce (Picea rubens Sarg.) occurring on some of the higher mountaintops.

\section{Vegetation sampling}

The data for this study were collected from 1997 to 2000 as part of several larger efforts to document the distribution of forest types within the Catskill Mountains of southeastern 
Fig. 1. Location of the Catskill Mountains, N.Y.

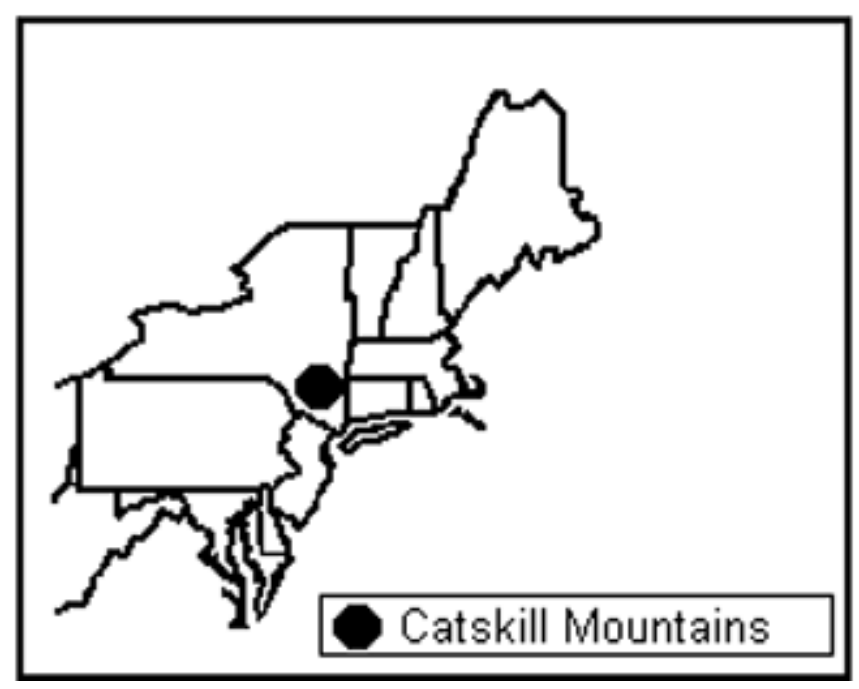

N.Y. Consequently, data reported here were collected by three similar methods used to determine relative basal areas of all canopy species, including beech.

Two methods consisted of the stratified random sampling of 10 watersheds dispersed throughout the Catskill Mountain Preserve, ranging in size from 63 to 476 ha. For both of these methods, stands were sampled along a series of transects perpendicular to the stream axis. Along each transect, one stand was sampled at a randomly chosen elevation within each 100-m elevation band. This was done so that sample distribution among elevation bands was proportional to the land area covered by that elevation band. The total number of sampled stands within each watershed was proportional to its area; the nine largest watersheds ranged from 1 stand/21.5 ha to 1 stand/26.7 ha, and the smallest was 1 stand/15.8 ha. For both transect methods, each stand consisted of five plots, $6 \times 30 \mathrm{~m}$ each. In the first of these methods, used in five of the watersheds, the five plots were spaced $20 \mathrm{~m}$ apart along the contour. For the second transect method, used in the other five watersheds, the five plots were laid out within a larger $58 \times 90 \mathrm{~m}$ rectangle, one plot in each corner and one in the center. In this second transect method, the elevation for the stand was recorded as the elevation at the center plot. For both of these methods, the diameter at $1.6 \mathrm{~m}$ of all trees $>10 \mathrm{~cm}$ in the plots was recorded, and all stems $<10 \mathrm{~cm}$ and at least $1.6 \mathrm{~m}$ tall were tallied by species.

The third sampling method consisted of surveying three tracts of forest not necessarily composing a watershed (334, 962, and 920 ha) and sampling stands occurring at randomly chosen latitude and longitude coordinates evenly distributed across elevation. At each stand, four prism survey plots (metric wedge prism, BAF 2) were established within a hectare, one in the center of each quadrant. Species and diameter at breast height $(\mathrm{DBH})$ of each tree included by the prism were recorded.

For all three sampling methods, organic horizon (Oe and $\mathrm{Oa}$ ) soils were collected from each stand for $\mathrm{C}: \mathrm{N}$ analysis. Soils were dried, ground, and $\% \mathrm{C}$ and $\% \mathrm{~N}$ were measured on a LECO element analyzer. Also, in each sampling method, every beech individual $>10 \mathrm{~cm}$ was assigned a rank for beech bark disease severity using the following scale of 1-5:
1. Very little or no sign of either causal agent (Cryptococcus or Nectria).

2. Cryptococcus present; bark beginning to crack; tree still shows vigor. Canopy at least $75 \%$ intact.

3. Bark heavily cracked; significant cankering from Nectria colonies; some crown damage or limb loss. Canopy $25-75 \%$ intact.

4. Bark severely cracked; large girdling cankers; significant crown loss or snag. Canopy $<25 \%$ intact.

5. Tree dead because of BBD.

\section{Data analysis}

For data analysis purposes, the prism plot, stand, and tract-level data from the third sampling method were considered equivalent in spatial scale to the plot, stand, and watershed-level data from the two transect methods, respectively. Henceforth, we will use "plot" to refer to one $6 \times$ $30 \mathrm{~m}$ (fixed area plots) or one $\sim 25 \mathrm{~m}$ radius (prism plot) sampled area, "stand" to refer to the clusters of plots within an area of $\sim 1$ ha, and "tract" to refer to the clusters of stands in watersheds or tracts ranging from 63 to 920 ha. "Elevation band" refers to 100-m intervals of elevation, and "elevation zone" refers to high (1000-1300 m), mid (600-1000 m), and low (300-600 m) elevation forests.

When calculating mean BBD ranks for each spatial scale (plot, stand, elevation band, elevation zone, and tract), means were weighted by basal area to correct for the prism method's slight bias toward sampling larger trees (Avery and Burkhart 1994). The mean absolute difference between the weighted and unweighted mean BBD ranks was 0.152 (SD = $0.103)$ at the tract level and $0.177(\mathrm{SD}=0.178)$ at the stand level. All statistical analyses were performed using the SAS statistical package (SAS Institute Inc. 1990). We used simple descriptive statistics (mean, standard error) to characterize the mean and variance in the data set and used the CORR and GLM procedures in SAS (SAS Institute Inc. 1990) for correlation and analysis of variance.

\section{Results}

Beech was found in 108 of 136 (79\%) stands ranging from 320 to $1232 \mathrm{~m}$ elevation. BBD was found in all 108 stands containing beech, and BBD-induced mortality was found in $45(42 \%)$ of these 108 stands. The relative basal area of beech $>10 \mathrm{~cm} \mathrm{DBH}$ (beech basal area/all spp. basal area) was found to vary between 0 and $100 \%$ at the plot level, 0 and $66 \%$ at the stand level, and 0.4 to $24 \%$ at the tract level. The largest percentage of beech stems (53\%) occurred in the smallest $(10.0-19.9 \mathrm{~cm})$ diameter class, and the percentage of stems in each successively larger class was approximately half the previous one (Table 1). The largest diameter class $(50+\mathrm{cm} ; \max \mathrm{DBH}=62.5 \mathrm{~cm})$ contained only $1 \%$ of all beech stems measured.

Most beech stems encountered were assigned disease ranks of 2 or 3 , with rank 1 (little or no infestation) being extremely uncommon ( $n=3,0.2 \%$ of all stems) and only occurring in the $10.0-10.9 \mathrm{~cm}$ diameter class (Table 1$)$. The percentage of rank 2 stems within each diameter class decreased as diameter class increased, and the percentage of rank 5 stems within each diameter class increased as diameter class increased (Table 1). The severity of BBD differed significantly among diameter classes (ANOVA, $p<0.0001$ ). 
Table 1. Distribution of beech bark disease (BBD) severity rankings and mortality rates by diameter class, Catskill Mountains, N.Y.

\begin{tabular}{|c|c|c|c|c|c|c|c|c|c|}
\hline \multirow[b]{2}{*}{$\begin{array}{l}\text { Diameter class } \\
(\mathrm{cm})\end{array}$} & \multirow[b]{2}{*}{$\begin{array}{l}\% \text { total } \\
\text { stems }\end{array}$} & \multicolumn{5}{|c|}{$\%$ individuals assigned each $\mathrm{BBD}$ ranking } & \multirow[b]{2}{*}{$\begin{array}{l}\text { Mean BBD } \\
\operatorname{rank}^{a}\end{array}$} & \multirow[b]{2}{*}{ SE } & \multirow[b]{2}{*}{$\% \mathrm{M}^{l}$} \\
\hline & & 1 & 2 & 3 & 4 & 5 & & & \\
\hline $10.0-19.9$ & 53 & 0.5 & 51 & 27 & 14 & 8 & $2.78 \mathrm{c}$ & 0.04 & 8 \\
\hline $20.0-29.9$ & 27 & 0 & 30 & 36 & 22 & 12 & $3.15 b$ & 0.05 & 12 \\
\hline $30.0-39.9$ & 12 & 0 & 19 & 46 & 20 & 15 & $3.31 \mathrm{ab}$ & 0.08 & 15 \\
\hline $40.0-49.9$ & 6 & 0 & 20 & 45 & 17 & 18 & $3.33 \mathrm{ab}$ & 0.12 & 18 \\
\hline $50.0+^{c}$ & 1 & 0 & 15 & 37 & 26 & 22 & $3.58 \mathrm{a}$ & 0.20 & 23 \\
\hline All stems $>10$ & 100 & 0.2 & 39 & 33 & 17 & 11 & 2.99 & 0.03 & 11 \\
\hline
\end{tabular}

The mean BBD rank for the smallest diameter class (10.0$10.9 \mathrm{~cm}$ ) was significantly lower than all other classes, and the largest diameter class had a BBD rank significantly higher than the two smallest classes (Table 1). Percent mortality also increased as diameter class increased (Table 1).

Strong correlations between BBD severity and relative beech basal area were not evident at the plot or stand spatial scale (adj. $r^{2}=0.003, p=0.1559, n=353$; adj. $r^{2}=0.05$, $p=0.0139, n=108$, respectively), nor was BBD severity strongly correlated to plot or stand elevation (adj. $r^{2}=0.03$, $p=0.0014$; adj. $r^{2}=0.09, p=0.0014$, respectively), stand or mean tract soil $\mathrm{C}: \mathrm{N}$ ratio (adj. $r^{2}=0.03, p=0.0518$; adj. $r^{2}=0.00, p=0.8347$, respectively), or the basal area of any other species at any spatial scale. However, both relative beech basal area and BBD severity tended to be highest in midelevation stands (Fig. 2). When stands are grouped by elevation zone, midelevation stands $(600-1000 \mathrm{~m})$ have a significantly higher (ANOVA, $p=0.0047$ ) relative beech basal area $(16 \%)$ than high elevation $(1000-1300 \mathrm{~m}, 7 \%$ beech) and low elevation (300-600 m, 9\% beech) stands, as well as a significantly higher (ANOVA, $p<0.0001$ ) mean BBD rank (3.22) than high elevation (2.76) or low elevation (2.41) stands. Furthermore, when grouped into 100-m elevation bands, the mean stand relative beech basal area was moderately correlated to the mean stand BBD severity (Fig. 3, adj. $\left.r^{2}=0.41, p=0.0377\right)$. This relationship is stronger (adj. $r^{2}=0.60, p=0.0143$ ) if the 1100-1199-m elevation band data point is excluded from the calculations. This point represents only five stands, and they are at the upper elevation limit for beech in this area. Environmental stresses at higher elevations may have caused trees in these stands to be weakened and, therefore, exhibit more severe BBD than stands of equal beech basal areas at lower elevations.

When stands were grouped by tract, relative beech basal area was more strongly correlated with mean BBD rank (Fig. 4, adj. $r^{2}=0.72, p=0.0001$ ). When percentage of stems ranked 4 or 5 was substituted for mean BBD rank, this relationship was stronger still $\left(\operatorname{adj} . r^{2}=0.82, p=0.0001\right)$.

\section{Discussion}

\section{BBD severity in the Catskill Mountains}

\section{Beech abundance}

The present abundance of beech in the Catskills as determined by this study is comparable with its distribution in
Fig. 2. (a) Fagus grandifolia relative basal area of sampled stands (\% of total; $n=136$ ). (b) Mean beech bark disease (BBD) ranks for sampled stands $(n=108)$, weighted by basal area. Elevation band values are plotted as the midpoint of each 100-m band. Error bars represent standard errors.
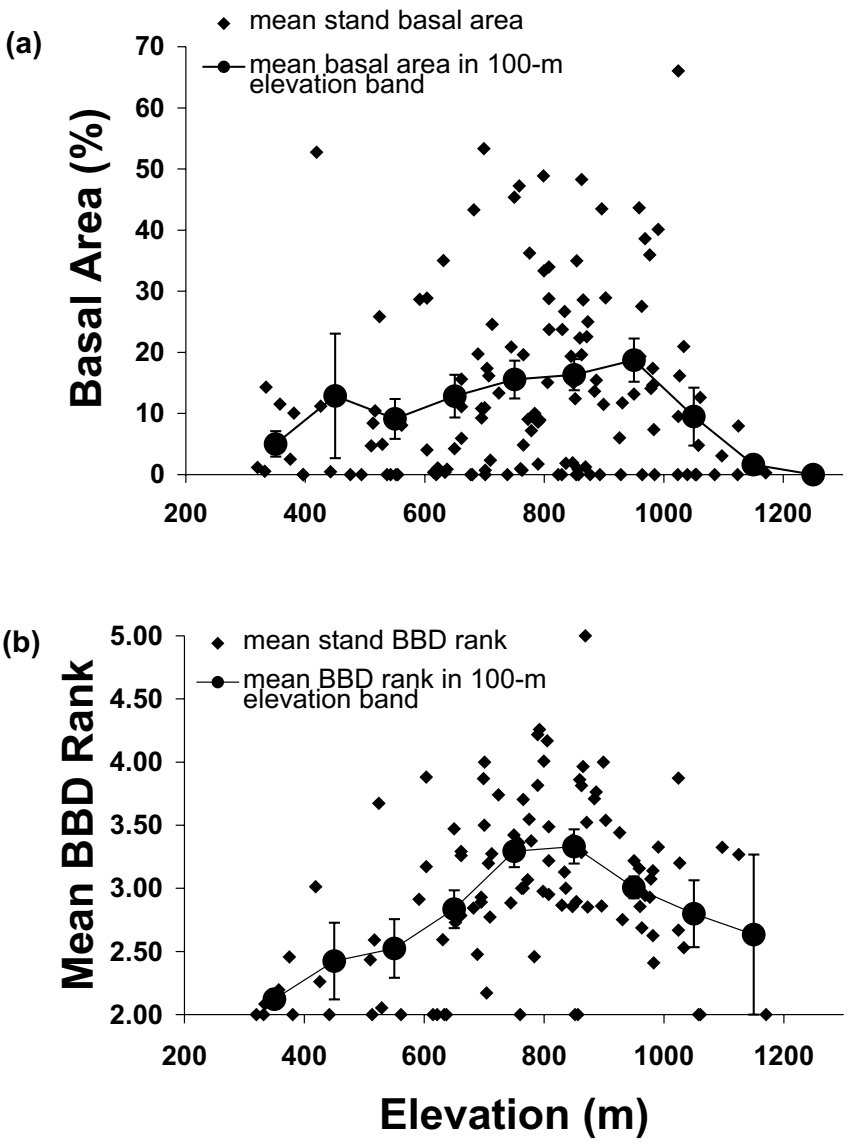

other northern hardwood forests of New York (Fahey 1998), New England (Twery and Patterson 1984), and Ohio (Forrester and Runkle 2000), as well as data collected from the Catskills in the early 1960s. McIntosh (1972) found that beech composed $12.8 \%$ of the total tree density in the Catskills based on data collected from 1960 to 1963 . We found beech to compose $17 \%$ of the total density. However, historical data compiled from land survey records ca. 1750 and 1800 indicate that the relative percentage of beech at 
Fig. 3. Fagus grandifolia relative basal area (\% of total) and mean beech bark disease (BBD) rank within 100-m elevation bands. Points represent the mean of all stands surveyed within 100-m elevation bands between 300 and $1200 \mathrm{~m}$. Error bars represent standard errors; mean $\mathrm{BBD}$ ranks are weighted by basal area.

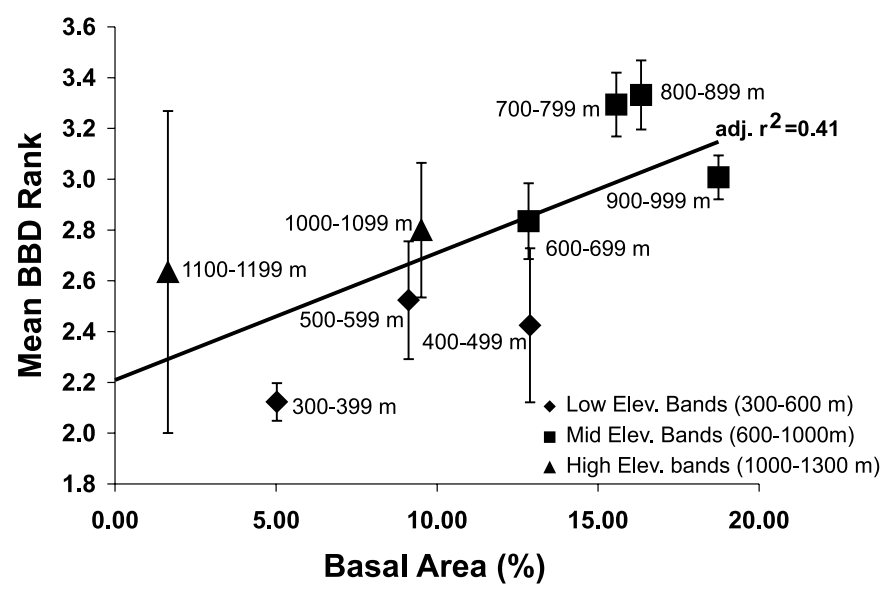

Fig. 4. Fagus grandifolia relative basal area (\% of total) and mean beech bark disease (BBD) rank for all tracts. Points represent the mean of all stands surveyed within tracts of land ranging from 63 to 960 ha. Error bars represent standard errors; stand BBD ranks were weighted by basal area.

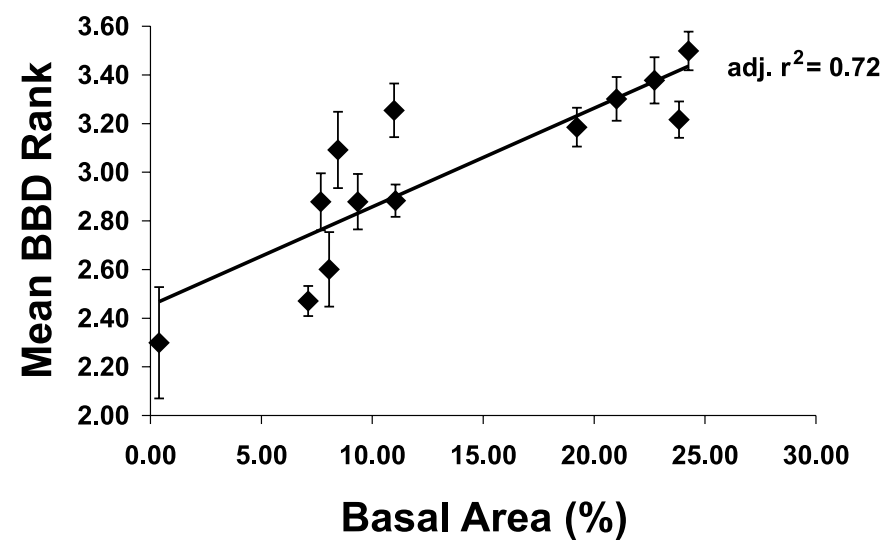

that time was much higher, at $49.5 \%$ of the overall density (McIntosh 1962).

\section{BBD prevalence}

Data collected from 1950 to 1957 (Zabel et al. 1958) show BBD present in eight counties of the Catskill region, with a high percentage of all age classes infected with both Cryptococcus and Nectria and BBD-induced mortality rates ranging from 65 to $81 \%$. By 1961, the state of BBD in the same eight Catskill counties was said to be "severe" (Zabel 1961). There have been many other influences on the Catskill landscape over the last 200 years, including logging, agriculture, and forest fires, yet the drastic decline in beech between ca. 1800 and the 1960s (McIntosh 1972) is most likely mainly attributable to the documented effects of BBD introduction in the 1940s.

The high mortality rates during the 1950 s reported by Zabel et al. (1958) and the dramatic drop in beech densities by 1963 reported by McIntosh (1972) suggest that the killing front (Shigo 1972) of BBD was moving through this part of N.Y. in the mid 1950s and early 1960s. Mortality data from other northern hardwood forests experiencing the killing front stage of the disease (Mize and Lea 1979) are consistent with 1950s Catskill mortality data. This period of high mortality is what Houston (1994) calls "phase one" of BBD, which "encompasses the effects resulting from the epidemic invasions and buildups of scale and pathogens" and is comparable with the cumulative effects of the advancing front and killing front stages described by Shigo (1972). The truncated range of beech diameter classes found in our study (Table 1) most likely reflects the legacy of this wave of high mortality during the 1950s. Many large stems would have been lost during this period and would therefore be less likely to be encountered in our surveys.

"Phase two" of Houston's (1994) BBD progression consists of "the effects of the established causal complex on the young, small beech trees arising in the aftermath of heavy mortality or salvage". In these long-affected stands, the effects of the disease on beech trees are manifested in reduced vigor and growth and increased deformity and defect of individuals rather than the widespread mortality of phase one. Twery and Patterson (1984) found damage from BBD in New England aftermath forests to be "a slow cumulative process causing more growth loss than mortality". The current state of BBD in the Catskills fits this profile of Houston's phase two. Affected stands in the Catskills do consist of smaller deformed trees, and many contain dense thickets of beech sprouts. The mortality rates we found in this study are much lower than historic BBD-induced mortality rates of the Catskills, as well as the mortality rates from other northeastern forests experiencing the killing phase of the disease complex. This shift from Houston's phase one to phase two marks the establishment of BBD as an endemic component of the Catskill forests.

\section{BBD distribution in the Catskills}

On a regional scale, it appears that the spread of BBD across the landscape will ultimately be checked only by the natural distribution of beech and extreme winter temperatures. In this study, we were interested in what might be controlling the distribution of the disease on smaller spatial scales. The success of a wind- and animal-borne dispersal strategy such as that of Cryptococcus would largely depend upon the prevalence of suitable hosts within the shadow of dispersal. Our tract-level data supported this idea. We found that the relative basal area of beech within a tract was positively correlated to the mean BBD rank assigned to trees within that tract. Assuming that each susceptible beech tree is a potential point of introduction, this result suggests that beech trees within tracts containing a higher concentration of potential points of introduction are currently more severely affected than those in tracts with fewer potential points of introduction. As BBD moved into the Catskills, tracts containing more beech would have had greater chances of becoming affected sooner than tracts with fewer beech and would exhibit a more severe stage of disease progression on individual trees at the time of our survey. Since the great majority of large affected individuals are eventually killed by the disease, the relative beech basal area - BBD se- 
verity correlation is most likely a function of the amount of time that has passed since a tract was first infected rather than any physiological differences between beech individuals in tracts that are densely or sparsely populated with beech.

Our data do not show a strong correlation between relative beech basal area and mean BBD rank at the stand level. We think it likely that some stands with low relative beech basal areas and high BBD ranks may have been affected via adjacent and more dense beech stands, which in turn were affected early in the spread of BBD into the region. Such stands would have higher average BBD ranks than stands of equal relative beech basal area that were far from large concentrations of beech. Conversely, some stands with high beech basal areas may have consisted of susceptible but highly tolerant individuals and, therefore, had low average BBD ranks. When grouped by elevation band, however, the stand-level data suggest that at the time of our survey, BBD was most severe at elevations that tend to harbor more beech and had not yet become severe at elevations that have less beech.

The variation in BBD severity across the landscape is undoubtedly influenced by variables other than the abundance of beech. The successful arrival of Cryptococcus eggs or nymphs to an individual tree or stand does not guarantee the establishment of BBD or the widespread mortality found in heavily infested areas. Robinson (1999) compiled several potential sources of small-scale spatial variability in BBD severity inherent to beech: (1) clusters of genetically resistant individuals resulting from clonal regeneration; (2) tolerant individuals that are susceptible to BBD yet are longlived; and (3) variable amino $\mathrm{N}$ concentrations in bark and resulting variability in food quality for Cryptococcus. Once a stand has been affected, other local conditions unrelated to beech physiology may also become more important than relative beech basal area in the success of the disease complex. Wargo (1988) and Latty et al. (2003) found BBD to be more severe on trees with higher $\mathrm{N}$ concentrations in bark tissue. Although in this study we do not have bark $\mathrm{N}$ data, we found no correlation between BBD severity and soil C:N ratio, a general measure of site N status (Lovett et al. 2003). Twery and Patterson (1984) suggested that the density of hemlock in a stand may be an important factor in local BBD severity, since it increases humidity within the stand and provides shade for the scale populations against cycles of freeze and thaw during the winter. Our study found no significant correlation between hemlock basal area or hemlock density and BBD severity at either the stand or tract level, nor was the shading effect of aspect associated with disease severity. Houston and Valentine (1988) found that local climate conditions such as extreme winter temperatures and heavy autumn rainfalls can temporarily reduce the population of Cryptococcus. However, the narrow range of these variables occurring within our study area is unlikely to explain the variation in severity we observed.

In summary, we found that the Catskill forests appear to be in the aftermath stage of BBD progression, following the killing front stage in the 1950s and early 1960s. BBD infection is nearly ubiquitous in these forests at present, and most larger beech trees show canopy deterioration from the disease. The pattern of BBD occurrence suggests that its distri- bution and severity is controlled by the abundance of beech, both along elevation gradients and at the tract scale (60$1000 \mathrm{ha})$, but not at the stand scale ( 1 ha).

\section{Acknowledgements}

This research was supported by the USDA NRI Competitive Grants Program (grant 96-35101-3126), the National Science Foundation (DEB 9981503), and the A.W. Mellon Foundation. We thank many able research assistants at Institute of Ecosystem Studies and University of Kentucky for help in the field and laboratory, especially Becky Brown, Heather Kratz, Andri Kukas, Miriam Osredkar, Susan Patterson, and Chuck Schirmer. This is a contribution to the program of the Institute of Ecosystem Studies. This study (02-09-110) is also connected with a project of the Kentucky Agricultural Experiment Station and is published with the approval of the director.

\section{References}

Avery, T.E., and Burkhart, H.E. 1994. Inventories with point samples. In Forest measurements. 4th ed. McGraw-Hill, New York. Chap. 11. p. 237.

Blanchard, R.O., and Tattar, T.A. 1981. Disease: beech bark disease. In Field and laboratory guide to tree pathology. Academic Press Inc., New York. pp 114-119.

Boyce, J.S. 1961. Beech bark disease. In Forest pathology. McGraw-Hill, New York. pp. 284-285.

Canham, C.D. 1988. Growth and canopy architecture of shadetolerant trees: response to canopy gaps. Ecology, 69: 786-795

DiGregorio, L.M., Krasny, M.E., and Fahey, T.J. 1999. Radial growth trends of sugar maple (Acer saccharum) in an Alleghany northern hardwood forest affected by beech bark disease. J. Torrey Bot. Soc. 126(3): 245-254.

Ehrlich, J. 1934. The beech bark disease, a Nectria disease of Fagus, following Cryptococcus fagi (Baer.). Can. J. Res. 10: 593-692.

Fahey, T.J. 1998. Recent changes in an upland forest in southcentral New York. J. Torrey Bot. Soc. 125(1): 51-59.

Forrester, J.A., and Runkle, J.R. 2000. Mortality and replacement patterns of an old-growth Acer-Fagus woods in the Holden Arboretum, northeastern Ohio. Am. Midl. Nat. 144(2): 227-242.

Hepting, G.H. 1971. American beech, Fagus grandifolia: stem diseases. In Diseases of forest and shade trees of the United States. U.S. Dep. Agric. Agric. Handb. 386. pp. 164-165.

Houston, D.R. 1975. Beech bark disease: the aftermath forests are structured for a new outbreak. J. For. 73: 660-663.

Houston, D.R. 1984. What is happening to the American beech? Conservationist, 38(6): 22-25.

Houston, D.R. 1994. Major new tree disease epidemics: beech bark disease. Annu. Rev. Phytopathol. 32: 75-87.

Houston, D.R., and Valentine, H.T. 1988. Beech bark disease: the temporal pattern of cankering in aftermath forests of Maine. Can. J. For. Res. 18: 38-42.

Latty, E.F., Canham, C.D., and Marks, P.L. 2003. Beech bark disease in northern hardwood forests: the importance of nitrogen dynamics and forest history for disease severity. Can. J. For. Res. 33: 257-268.

Lovett, G.M., Weathers, K.C., and Arthur, M.A. 1999. Is nitrate in stream water an indicator of forest ecosystem health in the Catskills? In Proceedings of a Symposium: Catskill Ecosystem Health, Catskill Institute for the Environment, 22 October 1999, 
Delhi, N.Y. Edited by Morton S. Adams. Purple Mountain Press, Fleishmanns, N.Y. pp. 23-30.

Lovett, G.M., Weathers, K.C., and Arthur, M.A. 2002. Control of $\mathrm{N}$ loss from forested watersheds by soil carbon:nitrogen ratio and tree species composition. Ecosystems, 5: 712-718.

Lovett, G.M., Weathers, K.C., Arthur, M.A., and Schultz, J.C. 2003. Nitrogen cycling in a northern hardwood forest: Do species matter? Biogeochemistry, In press.

McGee, G.G. 2000. The contribution of beech bark diseaseinduced mortality to coarse woody debris loads in northern hardwood stands of Adirondack Park, New York, U.S.A. Can. J. For. Res. 30: 1453-1462.

McIntosh, R.P. 1962. The forest cover of the Catskill Mountain region, New York, as indicated by land survey records. Am. Midl. Nat. 68(2): 409-423.

McIntosh, R.P. 1972. Forests of the Catskill Mountains, New York. Ecol. Monogr. 42: 143-162.

McCullough, D.G., Heyd, R., and O'Brien, J.G. 2000. Biology and management of beech bark disease, Michigan's newest exotic forest pest [online]. Michigan State University, Michigan Society of American Foresters, Beech bark disease. Available from http://forestry.msu.edu/msaf/MainPage/BBdisease.htm [updated November 2000; cited 25 February 2003].

Mize, C.W., and Lea, R.V. 1979. The effect of the beech bark disease on the growth and survival of beech in northern hardwoods. Eur. J. For. Pathol. 9: 243-248.
Robinson, G.R. 1999. Land use history and spatial variability in the beech bark disease. In Proceedings of a Symposium: Catskill Ecosystem Health, Catskill Institute for the Environment, 22 October 1999, Delhi, N.Y. Edited by Morton S. Adams. Purple Mountain Press, Fleishmanns, N.Y. pp. 31-52.

SAS Institute Inc. 1990. SAS procedures guide, version 6. 3rd ed. SAS Institute Inc., Cary, N.C.

Shigo, A.L. 1972. The beech bark disease today in the Northeastern U.S. J. For. 70: 286-289.

Tainter, F.H., and Baker, F.A. 1996. Beech bark disease. In Principles of forest pathology. John Wiley \& Sons, New York. pp. 594-605.

Twery, M.J., and Patterson, W.A. 1984. Variations in beech bark disease and its effects on species composition and structure of northern hardwood stands in central New England. Can. J. For. Res. 14: 565-574.

Wargo, P.M. 1988. Amino nitrogen and phenolic constituents of bark of American beech, Fagus grandifolia, and infestation by beech scale, Cryptococcus fagisuga. Eur. J. For. Pathol. 18: 279-290.

Zabel, R.A. 1961. Important tree disease problems in New York. In Tenth annual reportof the joint legislative committee on natural resources. New York State Legis. Doc. 41. pp. 26-29.

Zabel, R.A., Silverborg, S.B., and Fowler, M.E. 1958. A survey of forest tree diseases in the Northeast - 1957. U.S. Dep. Agric. For. Serv. Northeast. For. Exper. Stn. Stn. Pap. 110. 